Premiere Educandum: Jurnal Pendidikan Dasar dan Pembelajaran

Volume 8(2) 173 - 184 Desember 2018

Copyright (C2018 Universitas PGRI Madiun

ISSN: 2088-5350 (Print) / ISSN: 2528-5173 (Online)

Available at: http://e-journal.unipma.ac.id/index.php/PE

Doi: $10.25273 /$ pe.v8i2.3308

\title{
Reciprocal teaching: Sebuah inovasi pembelajaran abad 21 untuk meningkatkan pemahaman konsep mahasiswa PGSD
}

\author{
Heti Murniayudi ${ }^{1}$, Ali Mustadi ${ }^{2}$, Mohammad Adam Jerusalem ${ }^{3}$ \\ 1,2,3 Pendidikan Dasar, Pascasarjana Universitas Negeri Yogyakarta \\ 1email: hetimurniayudi.2017@student.ac.id \\ 2email: ali_mustadi@uny.ac.id \\ 3email: adam_jerusalem@uny.ac.id
}

\begin{abstract}
This study aims to improve the understanding of the concept of Social Sciences for PGSD students by applying reciprocal teaching-learning models. This study is a type of Classroom Action Research (CAR) model of Kemmis and MC. Taggart. The subjects of this study were all students of PGSD class 2A with a total of 46 students. Data collection techniques using tests that are analyzed by quantitative descriptive. The success of this research can be shown through the results of the first cycle test showing the percentage of $75.3 \%$ in the interpreting indicator, and the percentage of $81.7 \%$ in the indicator explained. Then after being subjected to cycle II action obtained a percentage of $78 \%$ in the interpreting indicator and a percentage of $76.9 \%$ in the indicator explained. In cycle III there was an increase in the percentage of $95.3 \%$ in the interpreting indicator, and a percentage of $85.1 \%$ in the indicator explained. By looking at the results obtained in each cycle, it can be concluded that the application of reciprocal teaching-learning models can overcome problems in class $2 \mathrm{~A}$ related to understanding the concept of social studies for PGSD students. Hopefully, PGSD students will become more competent teacher candidates in social science knowledge. Through this learning model, it can enrich the lecturers' insight in planning a learning innovation.
\end{abstract}

Keyword: Reciprocal teaching, Learning innovation, Concept understanding

\begin{abstract}
Abstrak
Penelitian ini bertujuan untuk meningkatkan pemahaman konsep IPS Mahasiswa PGSD dengan menerapkan model pembelajaran reciprocal teaching. Penelitian ini merupakan jenis Penelitian Tindakan Kelas (PTK) model Kemmis dan MC. Taggart. Subjek penelitian ini adalah seluruh mahasiswa PGSD kelas 2A dengan jumlah 46 siswa. Teknik pengumpulan data menggunakan tes yang dianalisis dengan deskriptif kuantitatif. Keberhasilan penelitian ini dapat ditunjukkan melalui hasil tes siklus I menunjukkan persentase sebesar 75,3\% pada indikator menafsirkan, dan persentase sebesar $81,7 \%$ pada indikator menjelaskan. Kemudian setelah dikenai tindakan siklus II diperoleh persentase sebesar $78 \%$ pada indikator menafsirkan dan persentase sebesar $76,9 \%$ pada indikator menjelaskan. Pada siklus III terjadi peningkatan persentase sebesar 95,3\% pada indikator menafsirkan, dan persentase sebesar $85,1 \%$ pada indikator menjelaskan. Dengan melihat hasil yang diperoleh pada setiap siklusnya, maka dapat diambil kesimpulan bahwa penerapan model pembelajaran reciprocal teaching dapat dapat meningkatkan pemahaman konsep IPS pada mahasiswa PGSD. Harapannya mahasiswa PGSD akan menjadi calon guru yang lebih kompeten dalam segi pengetahuan ilmu sosial. Melalui model pembelajaran ini, dapat memperkaya wawasan dosen dalam merencanakan suatu inovasi pembelajaran.
\end{abstract}

Kata kunci: Reciprocal teaching, Inovasi pembelajaran, Pemahaman konsep 


\section{A. PENDAHULUAN}

Ilmu pengetahuan dan teknologi selalu mengalami perkembangan secara dinamis dari waktu ke waktu. Teknologi menghubungkan dunia menjadi tanpa batas walaupun dipisahkan jauh secara geografis (Daryanto; Karim, 2017). Sesuai dengan tujuan IPS pada abad 21 bahwa dalam era global menuntut kualitas pengetahuan yang mengarah pada pembentukan kecakapan hidup (life skill), sehingga pengetahuan melandasi segala alternatif pemecahan masalah dalam berbagai bidang kehidupan (Mulyasa, 2015). Implikasinya terhadap pendidik maupun calon pendidik dalam perspektif global memerlukan wawasan yang unggul diiringi dengan reformasi berbagai aspek pembelajaran pada semua jenis dan jenjang pendidikan, mulai dari pendidikan dasar hingga perguruan tinggi. Kebutuhan abad 21 seperti sekarang ini memang sangat diperlukan keterampilan pengetahuan (kognitif) yang mendalam dalam konteks kehidupan mengenai suatu masalah, peristiwa atau kejadian. Bloom, (1956) membagi ranah kognitif atau pengetahuan ke dalam taksonomi enam kelas pokok yang meliputi: C1 (pengetahuan), C2 (Pemahaman), C3 (Aplikasi), C4 (Analisis), C5 (Sintesis), dan C6 (Evaluasi). Salah satu cakupan domain kognitif adalah kemampuan pemahaman. Apabila guru atau pendidik memiliki tingkat pemahaman konsep yang tinggi, maka secara otomatis akan dapat menyikapi berbagai fenomen-fenomena sosial yang sedang terjadi. Apabila terjadi penerapan konsep yang salah kepada peserta didik, maka akan menimbulkan miskonsepsi yang berdampak pada peserta didik. Kokkonen, Tommi (2017) mengemukakan bahwa permasalahan miskonsepsi tersebut menjadi masalah konsep belajar, dimana pemahaman konsep merupakan bagian dari struktur komplek pengetahuan. Sands, David (2014) menjelaskan bahwa hal yang perlu dilakukan adalah dengan memfokuskan kesalahpahaman dengan cara mengukur secara kualitatif dan kuantitaif dalam mengevaluasi pengetahuan mereka. Dengan cara ini akan meluruskan kesalahpahaman dan mengajari peserta didik untuk mengenali letak permasalahan dan alasannya.

Berdasarkan hasil wawancara dengan dosen mata kuliah IPS dan observasi dengan mahasiswa PGSD kelas 2A di Universitas Ahmad Dahlan pada tanggal 7 Maret 2018, dapat diketahui permasalahan sebagai berikut. Pertama, ketika dosen menunjuk beberapa mahasiswa untuk memberikan tanggapan dan jawaban atas materi tertentu sebagian mahasiswa menjawab kurang tepat. Hal ini membuktikan bahwa pada tingkat kemampuan pemahaman mahasiswa terhadap konsep IPS masih rendah. Bila hal ini terus terjadi, maka akan berdampak pada kualitas mengajar mahasiswa PGSD di kemudian hari, ketika menjadi guru sekolah dasar. Kedua, kurangnya minat mahasiswa dalam mengikuti perkuliahan IPS, dapat diamati saat 
perkuliahan berlangsung ada mahasiswa yang kurang memerhatikan dosennya yang sedang mengajar seperti mengobrol, bermain gadget yang tidak sesuai dengan konteks pembelajaran, mengantuk dan sebagainya. Ketiga, ada beberapa mahasiswa yang mengulang mata kuliah tersebut. Setelah dilakukan wawancara terhadap salah satu mahasiswa, ia mengakui bahwa materi perkuliahan IPS memang sangat banyak dan sulit, sehingga untuk benar-benar memahami konsep ilmu sosial kurang maksimal. Materi ilmu sosial yang paling sulit adalah pada materi sejarah, dimana banyak yang harus dihapalkan dan dipahami secara mendalam. Penyebab dari ketiga masalah di atas bisa disebabkan karena penggunaan metode pembelajaran yang kurang sesuai dengan kebutuhan mahasiswa pada abad 21, dimana perlu adanya paradigma baru menghadapi tantangan-tantangan di abad 21. Oleh karena itu, diperlukan penggabungan antara proses berfikir, lingkungan dan teknologi yang sesuai dengan abad 21 .

Dari uraian di atas, maka perlu suatu usaha dari dosen dan peneliti untuk mengatasi permasalahan tersebut, terutama pada pemahaman konsep IPS. Pemahaman (comprehension) merupakan kemampuan seseorang dalam memahami sesuatu untuk diketahui dan diingat. Dengan kata lain, memahami adalah mengetahui tentang sesuatu dan dapat melihatnya dari berbagai segi. Mahasiswa dikatakan telah memahami sesuatu apabila ia dapat memberikan panjelasan atau memberi uraian yang lebih rinci tentang hal tersebut dengan menggunakan kata-katanya sendiri (Sudijono, 1996). Pemahaman konsep juga memungkinkan seseorang dalam mentransfer pengetahuan maupun pengertian mengenai suatu fenomena ke dalam berbagai macam kondisi yang sudah dianalisis sebelumnya melalui cara belajar maupun cara berpikir setiap individu mengenai suatu ilmu.

Selanjutnya Kurniasih, I \& Sani, (2016) menguraikan pada tahap memahami terdiri dari (1) menafsirkan (interpreting) atau menggambarkan ulang dengan mengubah dari satu bentuk ke bentuk lain. (2) memberi contoh (exampliying) yaitu menemukan contoh yang sesuai untuk mengilustrasikan suatu konsep. (3) mengklasifikasikan (classifying) atau mengelompokkan konsep yang ada pada suatu materi. (4) meringkas (summarizing) yaitu meringkas sesuatu yang umum menjadi lebih ringkas. (5) menduga (inferring) atau mengambil kesimpulan atau memprediksi dari informasi yang disajikan. (6) membandingkan (compairing) yaitu mencocokan antara dua ide, objek dan hal-hal yang serupa. (7) menjelaskan (expalining) yaitu membangun hubungan sebabakibat dari suatu sistem.

Perkuliahan IPS idealnya melibatkan mahasiswa secara aktif, agar dapat membangun pengalaman nyata. Pemahaman konsep merupakan bentuk pemahaman yang kompleks, oleh karena itu diperlukan suatu model pembelajaran yang dapat merangsang kemampuan kognitif mahasiswa. Model pembelajaran reciprocal 
teaching diperkenalkan oleh Palinscar dan Brown (1984) yang mendeskripsikan konsep dasar model reciprocal teaching sebagai sebuah aktivitas pembelajaran dalam bentuk dialog antara pendidik dan peserta didik. model ini tersusun atas empat strategi yaitu merangkum/meringkas, membuat pertanyaan, mengklarifikasi /menjelaskan, dan memprediksi. Selanjutnya Arends, (2012) mendefinisikan reciprocal teaching sebagai suatu prosedur pengajaran yang dirancang untuk mengajarkan kepada siswa tentang strategistrategi kognitif untuk membantu siswa dalam memahami materi pembelajaran dengan baik.

Adapun penjelasan mengenai strategi-strategi reciprocal teaching dalam perkuliahan IPS menurut Garderen (2004) terdiri dari empat komponen sebagai berikut:

a. Mengklarifikasi (Clarifying)

Pada tahap ini, mahasiswa diberikan materi pelajaran yang terkait dan diwajibkan untuk membaca bahan bacaan tersebut. Pada tahap klarifikasi, satu siswa bertugas membimbing dan memimpin teman sekelompoknya dalam mengklarifikasi materi. Mengklarifikasi materi dapat dilakukan melalui sumber buku pegangan dan internet. Mahasiswa dibebaskan untuk mencari sumber dari manapun asal dapat dipertanggungjawabkan secara valid.

b. Memprediksi (Predicting)

Mahasiswa diajak untuk memprediksi hubungan antar konsep pembelajaran, baik konsep yang telah dipelajari maupun konsep pada materi yang sedang dipelajari. Kegiatan ini dilakukan oleh mahasiswa untuk menghubungkan konsep baru dengan materi yang telah dipelajari dengan menyajikan fenomena faktual dan kontekstual. Sehingga diharapkan setiap mahasiswa bisa mengkonstruksi pengetauan mereka agar lebih berkembang.

$\begin{array}{cr}\text { c. Membuat } & \text { pertanyaan } \\ \text { (Questioning) } & \\ \text { Mahasiswa } & \text { membuat } \\ \text { pertanyaan/soal secara } & \text { tertulis } \\ \text { kemudian menjawabnya. } & \text { Pada }\end{array}$
kegiatan ini mahasiswa bisa melakukan crosscheck mengenai materi yang telah diperoleh dan materi yang belum dikuasai dari keseluruhan konsep yang diajarkan. Membuat pertanyaan bisa dilakukan dengan saling tanya jawab antar mahasiswa sesame kelompok ataupun bertuka dengan kelompok lain.

\section{d. Merangkum (Summarizing)}

Pada kegiatan ini, mahasiswa membuat rangkuman secara singkat dari materi yang telah dipelajari. Merangkum bertujuan untuk mengulas materi yang telah dipelajari sebelumnya, dengan bahasa dan katakata sendiri.

Pendidik abad 21 perlu mempertimbangkan model reciprocal teaching untuk diterapkan dalam praktik pembelajaran. Implikasi ini sangat bermanfaat bagi mahasiswa karena mereka sedang dipersiapkan untuk sukses dalam studinya, terutama dalam kemampuan memahami, membangun dan merekonstruksi makna. Pada tahap meringkas, merupakan strategi yang dapat mempercepat pembelajaran, terutama dalam keterampilan berpikir yang lebih dalam jangka waktu singkat jika dilaksanakan dengan baik. Melalui 
penerapan model pembelajaran reciprocal teaching diharapkan mahasiswa dapat meningkatkan pemahaman konsep karena dalam pembelajaran model ini mau tidak mau mahasiswa harus menguasai konsep materi secara individu (Wolmarans, 2016).

Penelitian ini perlu dilakukan untuk mengatasi permasalahan yang timbul di kelas dan dapat memberikan manfaat kepada mahasiswa PGSD agar kelak menjadi guru yang berkompeten pada abad 21. Batasan penelitian ini yaitu mengenai penerapan model pembelajaran model pembelajaran reciprocal teaching sebagai suatu inovasi pembelajaran pada abad 21 pada mahasiswa pendidikan guru sekolah dasar. Berbagai penelitian mengenai model pembelajaran reciprocal teaching telah dilakukan, seperti yang dilakukan oleh Argikas, Khuzaini, Argikas, \& Khuzaini, (2016) mengenai penerapan model reciprocal teaching untuk meningkatkan pemahaman konsep matematika siswa SMP. Penelitian tersebut menunjukkan keberhasilan penelitian pada mata pelajaran matematika dan subjek penelitian siswa SMP. Akan tetapi penelitian tersebut tidak meneliti pada konsep IPS dan subjek penelitiannya pun berbeda. Selanjutnya penelitian yang dilakukan oleh Ichsan (2013) mengenai pengembangan model pembelajaran terbalik (reciprocal teaching) pada mata kuliah matematika. Penelitian tersebut menunjukkan bahwa model pembelajaran reciprocal teaching dapat meningkatkan hasil belajar matematika. Penelitian yang dilakukan oleh Ichsan (2013) tentu berbeda dengan penelitian ini, dimana mata kuliah yang menjadi fokus penelitian adalah konsep dasar IPS. Lebih lanjut, penelitian yang dilakukan oleh Freihat \& Al-makhzoomi, (2012) yang meneliti tantang keefektifan langkah reciprocal teaching dalam peningkatan pemahaman bacaan di tingkat universitas. Sebagaian besar penelitian yang telah dilakukan sebelumnya digunakan untuk meningkatkan hasil, pemahaman konsep matematika, dan reading comprehension. Oleh karena itu, peneliti perlu melakukan penelitian mengenai penerapan model pembelajaran reciprocal teaching untuk meningkatkan pemahaman konsep IPS mahasiswa PGSD kelas 2A.

\section{B. METODE PENELITIAN}

Pendekatan yang digunakan dalam penelitian ini adalah Penelitian Tindakan kelas (PTK), artinya penelitian ini berbasis pada masalah di kelas 2A. Penelitian ini dipilih karena sesuai dengan permasalahan yang ada yaitu meningkatkan kemampuan pemahaman konsep IPS mahasiswa PGSD kelas 2A Universitas Ahmad Dahlan. Penelitian ini menggunakan rancangan model siklus Kemmis \& Mc. Taggart (Arikunto, 2006) yang masing-masing siklus terdiri dari: perencanaan (plan), tindakan (act) \& pengamatan (observe), dan refleksi (reflect). Penelitian diawali dengan merencakan dan melakukan observasi di kelas 2A serta wawancara dengan dosen pengampu mata kuliah IPS. Peneliti memeroleh permasalahan dan selanjutnya dilakukan penerapan 
model pembelajaran reciprocal teaching. Siklus ini dilakukan hingga permasalahan di lapangan telah

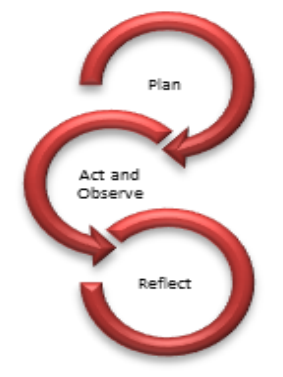

Gambar 1. Model Spiral Kemmis Mc Taggart (Arikunto, 2006:92)

Teknik tes berupa soal-soal yang disajikan dalam evaluasi di akhir siklus untuk memperoleh data dalam bentuk angka. Evaluasi digunakan untuk mengukur kemampuan pemahaman konsep IPS mahasiswa dengan mengerjakan soal-soal uraian. Pada siklus I menggunakan soal uraian berjumlah 5 soal sedangkan siklus II menggunakan soal uraian berjumlah 6 , dan soal siklus III sebanyak 5 soal uraian yang mencakup ke dua indikator menafsirkan dan menjelaskan. Penskoran pada tiap butir soal menggunakan rubrik penilaian dengan skor 4 atau 5 setiap soalnya. Adapun kategori hasil dari tes pemahaman konsep mahasiswa siklus I, II, dan III dalam penelitian ini melalui kategorisasi sebagai berikut. Tabel 1. Kategorisasi tes pemahaman konsep

\begin{tabular}{cc}
\hline Rentang & Kategori \\
\hline $0-20$ & Sangat kurang \\
\hline $21-40$ & Kurang \\
\hline $41-60$ & Cukup \\
\hline $61-80$ & Baik \\
\hline $81-100$ & Sangat baik \\
\hline (Dimodifikasi dari Arikunto, Suharsimi (2010)
\end{tabular}

teratasi dengan melihat peningkatan hasil tes mahasiswa PGSD memenuhi kriteria

keberhasilan.

\author{
Keterangan: \\ Siklus I: \\ 1. Perencanaan I \\ 2. Tindakan dan Observasi I \\ 3. Refleksi I \\ Siklus II: \\ 1. Perencanaan II \\ 2. Tindakan dan Observasi II \\ 3. Refleksi II \\ Siklus III: \\ 1. Perencanaan III \\ 2. Tindakan dan Observasi III \\ 3. Refleksi III
}


III dengan menerapkan model pembelajaran reciprocal teaching. Kegiatan pembelajaran yang mencakup dalam tahap pemahaman konsep pada penelitian ini dibatasi pada indikator berikut:

1. Menafsirkan (interpreting) atau mengartikan atau menggambarkan ulang dari bentuk satu ke bentuk lainnya.

2. Menjelaskan (expalining) berarti memkonstruktsi hubungan sebabakibat dari suatu sistem.

Keberhasilan penelitian ini dapat dilihat melalui hasil tes mahasiswa yang dapat dilihat pada tabel di bawah ini.

Tabel 2. Hasil rata-rata tes pemahaman konsep siklus I

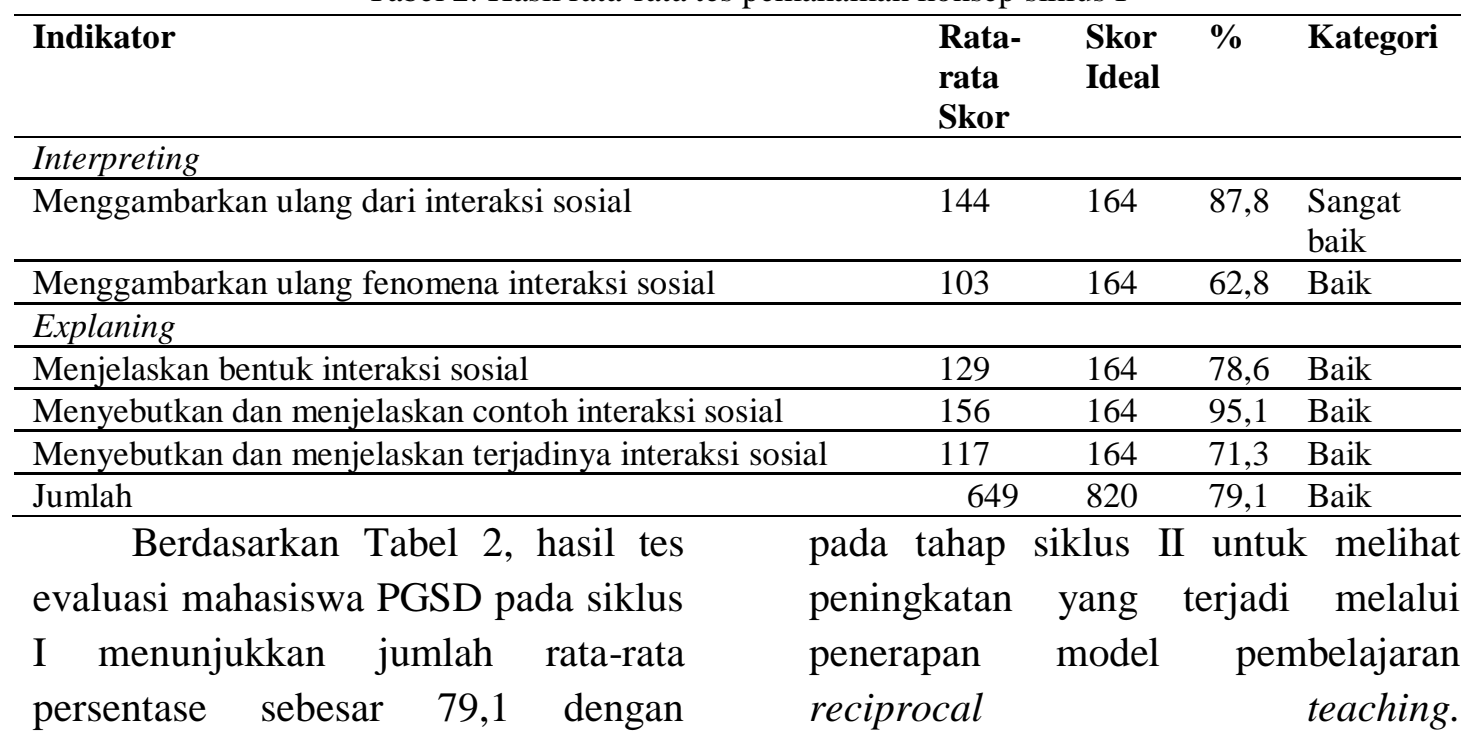

kriteria baik. Kemudian dilanjutkan

Tabel 3. Hasil rata-rata tes pemahaman konsep siklus II

\begin{tabular}{|c|c|c|c|c|}
\hline Indikator & $\begin{array}{l}\text { Rata- } \\
\text { rata } \\
\text { Skor }\end{array}$ & $\begin{array}{l}\text { Skor } \\
\text { Ideal }\end{array}$ & $\%$ & Kategori \\
\hline \multicolumn{5}{|l|}{ Interpreting } \\
\hline Menggambarkan ulang faktor-faktor tingginya tingkat kelahiran & 187 & 205 & 91,2 & $\begin{array}{l}\text { Sangat } \\
\text { baik }\end{array}$ \\
\hline Menggambarkan ulang fenomena arus urbanisasi & 165 & 205 & 80,4 & Baik \\
\hline Menggambarkan ulang dampak pertumbuhan penduduk tinggi & 128 & 205 & 62,4 & Baik \\
\hline \multicolumn{5}{|l|}{ Explaning } \\
\hline $\begin{array}{l}\text { Menyebutkan dan menjelaskan faktor alami pertumbuhan } \\
\text { penduduk }\end{array}$ & 132 & 205 & 64,3 & Baik \\
\hline Menjelaskan cara menghitung angka kasar & 200 & 205 & 97,5 & $\begin{array}{l}\text { Sangat } \\
\text { Baik }\end{array}$ \\
\hline $\begin{array}{l}\text { Menjelaskan dampak ledakan penduduk terhadap pembangunan } \\
\text { di Indonesia }\end{array}$ & 141 & 205 & 68,8 & Baik \\
\hline Jumlah & 953 & 1230 & 77,4 & Baik \\
\hline
\end{tabular}

jumlah persentase sebesar $1.7 \%$. bila 
Tabel 4. Hasil rata-rata tes pemahaman konsep siklus III

\begin{tabular}{|c|c|c|c|}
\hline \multicolumn{4}{|l|}{ Indikator } \\
\hline \multicolumn{4}{|l|}{ Interpreting } \\
\hline \multirow{2}{*}{\multicolumn{4}{|c|}{$\begin{array}{l}\text { Menggambarkan ulang maksud dari tenaga kerja, ke } \\
\text { kerja, dan pengangguran } \\
\text { Menggambarkan ulang usaha peningkatan mutu tena }\end{array}$}} \\
\hline & & & \\
\hline \multicolumn{4}{|l|}{ Explaning } \\
\hline \multicolumn{4}{|c|}{ Menjelaskan faktor-faktor yang mempengaruhi angk } \\
\hline \multicolumn{4}{|c|}{ Menyebutkan dan menjelaskan macam tenaga kerja } \\
\hline \multicolumn{4}{|c|}{$\begin{array}{l}\text { Menyebutkan dan menjelaskan dampak penganggur } \\
\text { keamanan lingkungan }\end{array}$} \\
\hline \multicolumn{4}{|l|}{ Jumlah } \\
\hline \multicolumn{4}{|c|}{$\begin{array}{l}\text { Berdasarkan Tabel } 4 \text { hasil rata- } \\
\text { rata tes menunjukkan peningkatan } \\
\text { yang sangat signifikan pada kedua } \\
\text { indikator dengan jumlah persentase } \\
\text { sebesar } 11,7 \% \text {. dengan kriteria sangat } \\
\text { baik. }\end{array}$} \\
\hline \multicolumn{4}{|c|}{$\begin{array}{l}\text { Tabel 5. Hasil persentasi tes pemahaman } \\
\text { konsep mahasiswa siklus I, II, dan III }\end{array}$} \\
\hline Indikator & Siklus 1 & Siklus 2 & Siklus 3 \\
\hline Interpreting & $75,3 \%$ & $78 \%$ & $95,3 \%$ \\
\hline explaining & $81,7 \%$ & $76,9 \%$ & $85,1 \%$ \\
\hline
\end{tabular}

Berdasarkan Tabel 5, siklus I sampai siklus III memiliki kategori baik. Persentase pemahaman konsep secara individu dapat dilihat pada diagram berikut.

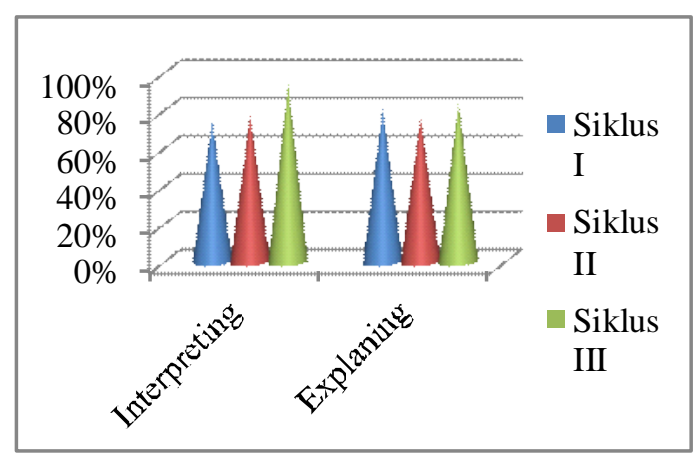

Gambar 2. Hasil Riset Pemahaman Konsep Mahasiswa Per Indikator.

Rata- Skor

Skor

Sker

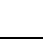

$162 \quad 172 \quad 94,1 \quad$ Sangat

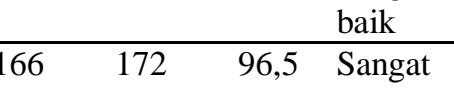
baik

\begin{tabular}{|c|c|c|c|}
\hline 153 & 172 & 88,9 & $\begin{array}{l}\text { Sangat } \\
\text { baik }\end{array}$ \\
\hline
\end{tabular}

\begin{tabular}{lcccl} 
& 153 & 172 & 88,9 & $\begin{array}{l}\text { Sangat } \\
\text { baik }\end{array}$ \\
\hline & 128 & 172 & 74,4 & Baik \\
\hline & 158 & 172 & 91,8 & $\begin{array}{l}\text { Sangat } \\
\text { baik }\end{array}$ \\
\hline
\end{tabular}

Penerapan model pembelajaran
reciprocal teaching dapat meningkatkan pemahaman konsep mahasiswa yang dapat diketahui melalui skor hasil tes yaitu siklus I dengan persentase sebesar $87,5 \%$ dan meningkat pada siklus II diperoleh persentase sebesar 93,7\%. Pada siklus I mahasiswa masih harus diperintah oleh dosen/peneliti dalam mengikuti kegiatan pembelajaran sesuai dengan langkah model pembelajaran reciprocal teaching. Beberapa mahasiswa juga tampak masih belum fokus terhadap alur perkuliahan. Kemudian pada siklus II peneliti kekurangan waktu dalam saat berlangsungnya tes siklus II sehingga beberapa mahasiswa belum menyelesaikan dengan baik. Hal ini terjadi karena jumlah soal uraian menjadi 6 nomor. Selain itu, materi pada siklus II sangat banyak dan terdapat rumus matematika untuk menghitung pertumbuhan penduduk mulai dari kematian dan kelahiran, sedangkan siklus III terjadi peningkatan yang cukup signifikan. Hal ini terjadi karena pada siklus III dilakukan selama 3 kali pertemuan 
sehingga dalam penguasaan materi menjadi lebih baik dan matang.

Berdasarkan Tabel 5, setiap indikator mengalami peningkatan setiap siklusnya, kecuali pada indikator explaning dari siklus I menuju siklus II yaitu ada penurunan sebanyak 4,6\%. Hal ini disebabkan karena pada saat evaluasi siklus II beberapa mahasiswa belum selesai sehingga diisi ala kadarnya karena keterbatasan waktu. Pada indikator ini, dari siklus II ke siklus III mengalami peningkatan sebesar 8,2\%. Pada indikator Interpreting selalu mengalami peningkatan di setiap siklusnya. Dari siklus I ke siklus II mengalami peningkatan 2,7\%. Dari siklus II ke siklus III mengalami peningkatan sebesar 17,3\%. sebesar $12,75 \%$. Dari siklus 3 ke siklus 4 juga mengalami peningkatan sebesar $1,45 \%$.

Keberhasilan penelitian ini menunjukkan bahwa penerapan model pembelajaran reciprocal teaching memang sangat berperan dapat meningkatkan pemahaman konsep IPS mahasiswa PGSD yang dpat dilihat dari peningkatan nilai dan proses pembelajaran. Hal ini karena model tersebut memang membuat mahasiswa lebih berperan aktif dalam pembelajaran (student center) sehingga model reciprocal teaching sering disebut sebagai pengajaran terbalik. Keberhasilan proses pembelajaran reciprocal teaching yang dilakukan oleh dosen diawali dengan tahap klarifikasi mahasiswa membaca materi dari berbagai macam sumber, dengan tahap ini secara tidak langsung mahasiswa dapat memperluas wawasan terkait dengan materi sesuai dengan pendapat Wolmarans, (2016) bahwa pada tahap klarifikasi mahasiswa memperjelas konsep yang belum dipahami bisa dilakukan dengan membaca. Tahap kedua, yaitu mahasiswa memprediksi atau menghubungkan konsep baru dengan materi yang telah dipelajari sebelumnya dengan media gambar sehingga mahasiswa bisa mengkonstruksi pengetahuan yang telah dimiliki. Hal ini sesuai dengan tahap yang disampaikan Wolmarans, (2016) bahwa tahap prediksi yaitu megkonfirmasi atau perbaiki prediksi sebelum, selama, dan setelah membaca bisa dengan tebakan cerdas tentang apa yang akan terjadi selanjutnya, petunjuk seperti judul, atau sebuah gambar. Selanjutnya pada tahap ketiga mahasiswa membuat pertanyaan/soal secara tertulis kemudian menjawabnya baik antar mahasiswa maupun antar kelompok. Sesuai dengan Wolmarans, (2016) pertanyaan memiliki peranan penting dalam pemantauan diri. Tahap terakhir yaitu mahasiswa membuat rangkuman secara singkat dari materi yang telah dipelajari sesuai pernyataan Wolmarans, (2016) pada tahap ini membuat catatan dan menceritakan kembali secara singkat dengan bahasa sendiri.

$\begin{array}{cclr}\text { Hal } & \text { yang } & \text { sama juga } \\ \text { diungkapkan } & \text { oleh } & \text { Mcallum \& }\end{array}$ Auckland (2014) mengemukakan bahwa pembelajaran reciprocal teaching yang meliputi empat strategi berpikir yaitu memprediksi, mengklarifikasi, menanyakan dan meringkas merupakan proses metakognitif untuk memberdayakan mahasiswa membangun pemikiran 
yang sistematis dan terarah (Cooper \& Greive, 2009). Pendidik pun dapat memantau kegiatan pembelajaran serta memberikan perancah kognitif bersama dengan siswa. Saleh, Hairus (2016) juga menyatakan bahwa model pembelajaran reciprocal teaching juga dapat merangsang kreativitas belajar mahasiswa dalam berpikir terutama pada keingintahuan yang tinggi terhadap suatu masalah, kemampuan dalam mengemukakan gagasan, mengerjakan soal, mengajukan pertanyaan, dan menjawab pertanyaan dengan baik.

Beberapa penelitian terdahulu, Mcallum \& Auckland, (2014) bahwa pembelajaran reciprocal teaching dapat membangun pemahaman, sehingga model pembelajaran ini sangat direkomendasikan dalam praktik pembelajaran yang menekankan pada pemahaman. Selain itu, model pembelajaran reciprocal teaching dapat merangsang kemampuan metakognitif. Hal yang sama diungkapkan oleh Vristiarum,Rida \& Ariyanto (2016) bahwa penerapan reciprocal teaching dapat meningkatkan pemahaman konsep. Peserta didik pun mampu mendominasi kegiatan belajar, sehingga lebih aktif dalam menyampaikan pendapat dan pertanyaan kepada pendidik. Selain itu Palincsar, (2017) juga mengemukakan bahwa tujuan dari model pembelajaran reciprocal teaching yaitu untuk memfasilitasi peserta didik secara individu maupun kelompok antara pendidik dan peserta didik dan antar sesama peserta didik dalam kegiatan pembelajaran yang bermakna. Strategi ini tidak hanya mengembangkan pemahaman tetapi juga memberikan kesempatan yang luas bagi peserta didik untuk memantau pemahaman mereka sendiri. Selain itu juga dapat meningkatkan kesadaran siswa dan pengaturan diri terhadap aktivitasnya sendiri sebagai instruksi metakognitif.

Berdasarkan pembahasan hasil penelitian diatas, maka dapat disimpulkan bahwa dengan menerapkan model pembelajaran reciprocal teaching dapat meningkatkan pemahaman konsep mahasiswa 2A PGSD. Harapannya mahasiswa PGSD akan menjadi calon guru yang lebih kompeten dalam hal pengetahuan IPS. Melalui model pembelajaran ini, tentu dapat memperkaya wawasan dosen dalam merencanakan suatu inovasi pembelajaran sesuai dengan abad 21 . Berdasarkan beberapa peneilitian yang telah dilakukan model pembelajaran reciprocal teaching dapat digunakan pada hampir semua mata pelajaran.

\section{SIMPULAN}

Berdasarkan hasil penelitian dan pembahasan yang telah diuraikan sebelumnya, dapat disimpulkan bahwa penerapan model pembelajaran reciprocal teaching dapat meningkatkan pemahaman konsep IPS mahasiswa PGSD 2A Universitas Ahmad Dahlan. Perkuliahan IPS lanjut dengan menerapkan model pembelajaran reciprocal teaching dapat mengajarkan kepada mahasiswa PGSD tentang strategistrategi kognitif dan membantu siswa untuk memahami materi pembelajaran dengan baik. Pada setiap akhir siklus, mahasiswa telah diberikan soal evaluasi yang 
digunakan untuk mengukur pemahaman konsep IPS mahasiswa pada perkuliahan IPS lanjut.

Penelitian yang telah dilakukan peneliti tidak bisa lepas dari hambatan yang ditemui selama penelitian, yaitu terjadinya penurunan pada indikator explaining dikarenakan hal yang tak terduga. Berdasarkan penelitian diatas, maka peneliti dapat memberikan beberapa saran sebagai berikut. Pertama bagi penelitian selanjutnya diharapkan memperluas subjek penelitian. Kedua untuk menghindari keterbatasan atau kondisi penurunan skor dapat diminimalisir dengan melakukan pengaturan atau manajemen waktu yang baik oleh dosen/peneliti saat proses pembelajaran dan mempertimbangkan jumlah soal evaluasi yang akan diberikan. Ketiga, berdasarkan hasil penelitian, model reciprocal teaching dapat diterapkan dan menjadi inovasi pembelajaran sesuai dengan abad 21 .

\section{DAFTAR RUJUKAN}

Arends, R. . (2012). Learning To Teach. New York: The McGrawHill Companies, Inc.

Argikas, T. B., Khuzaini, N., Argikas, T. B., \& Khuzaini, N. (2016). Penerapan model pembelajaran reciprocal teaching untuk meningkatkan pemahaman konsep matematika siswa kelas vii smp negeri 2 depok the application of reciprocal teaching method for improving the understanding of mathematics concept of 7 th grade students. Mercumatika, 1(1), 67-79.

Arikunto, S. (2006). Penelitian Tindakan Kelas. Jakarta: Bumi Aksara.
Arikunto, S. (2010). Prosedur Penelitian Suatu Pendekatan Praktek. Jakarta: Rineka Cipta.

Bloom, B. S. (1956). Taxonomy of Educational Objectives The Classification of Educational Goals. London: Longmans, Green and Co LTD.

Cooper, T., \& Greive, C. (2009). The Effectiveness of the Methods of Reciprocal Teaching: As Applied Within the NSW Primary Subject Human Society and Its Environment: An Exploratory Study. TEACH Journal of Christian Education, 3(1), 45-52.

Daryanto; Karim, S. (2017). Pembelajaran Abad 21. Yogyakarta: Gava Media.

Freihat, S., \& Al-makhzoomi, K. (2012). The Effect of the Reciprocal Teaching Procedure ( RTP ) on Enhancing EFL Students , Reading Comprehension Behavior in a University Setting. International Journal of Humanities and Social Science, 2(5), 279-291.

Ichsan. (2013). Pengembangan model pembelajaran terbalik ( reciprocal teaching ) pada mata kuliah matematika the developing of reciprocal teaching. Vokasi, IX(3), 186-199.

Kokkonen, T. (2017). Concepts and concept learning in physics the systemic view. University of Helsink.

Kurniasih, I \& Sani, B. (2016). Ragam Pengembangan Model Pembelajaran untuk Peningkatan Profesionalisme Guru. Jakarta: Kata Pena.

Mcallum, R., \& Auckland, C. W. (2014). Reciprocal Teaching: Critical Reflection on Practice. KAIRARANGA, 15(1), 26-35. 
Mulyasa, H. . (2015). Revolusi Mental Dalam Pendidikan. Bandung: Rosdakarya.

Palincsar, A. S. (2017). Using reciprocal teaching to support strategy instruction and language use among second. Contact Magazine, 44-52.

Saleh, H. (2016). Penerapan strategi pembelajaran terbalik ( reciprocal teaching ) untuk meningkatkan kreativitas belajar. Sigma, 2(1), 13-18.

Sands, D. (2014). Concepts and conceptual understanding: what are we talking about? Opinion Piece, 10(I), 7-11. https://doi.org/10.11120/ndir.201
4.00030

Sudijono, A. (1996). Pengantar Evaluasi Pendidikan. Jakarta: PT.Grafindo Persada.

Vristiarum, R. A. (2016). ( PTK di SMP Muhammadiyah 10 Surakarta Kelas IX Semester Gasal Tahun Ajaran 2015 / 2016 ). In Konferensi Nasional Penelitian Matematika dan Pembelajarannya (KNPMP I) (pp. 268-275). Surakarta: Universitas Muhammadiyah Surakarta.

Wolmarans, A. (2016). Reciprocal Teaching: a strategy for the 21st Century. CCEE (Curro Centre for Educational Excellence), 1-9. 